\title{
Critical assessment of Thalassia testudinum (turtle grass) aging techniques: implications for demographic inferences
}

\author{
James E. Kaldy ${ }^{1, *}$, Norma Fowler ${ }^{2}$, Kenneth H. Dunton ${ }^{1}$ \\ 'University of Texas at Austin, Marine Science Institute, 750 Channelview Drive, Port Aransas, Texas 78373, USA \\ ${ }^{2}$ University of Texas at Austin, Dept of Botany, Austin, Texas 78712, USA
}

\begin{abstract}
Variability in the time interval between the formation of successive leaves (i.e. the plastochron) directly influences estimates of seagrass shoot age. Age-frequency distributions were constructed for Thalassia testudinum short shoots from a shallow and a deep site in the Lower Laguna Madre, Texas, during the summers of 1995 and 1996. In each year the ages of 200 to 250 shoots, collected by coring, were estimated from leaf scars and annual leaf production rates. Two years of monthly leaf production measurements were used to calculate annual leaf production. The leaf production rate was site-specific: plants at the shallow site produced about 13 leaves $\mathrm{yr}^{-1}$ while plants from the deep site produced about 10 leaves $\mathrm{yr}^{-1}$; the $95 \%$ confidence limits around the mean were \pm 20 to $25 \%$. At the shallow site, the mean annual leaf formation rate during 1996 was $15 \%$ higher than during 1995 , indicating substantial interannual variability. Age-frequency distributions were adjusted to account for misclassification errors as a result of age-specific leaf initiation rates. The oldest shoot was estimated to be between 8 and $12 \mathrm{yr}$. Long-term leaf marking indicates that the seagrass $T$. testudinum in Lower Laguna Madre violates the assumption that the leaf production rate is constant and successive plastochrons are of equal duration. Reduced leaf formation rates during summer were likely caused by resource allocation to developing fruits and seeds. As a result of site-specific, seasonal, and interannual variability in annual leaf formation rates, the application of the plastochron method to estimate $T$. testudinum short shoot age is limited. Furthermore, a review of the literature indicates that age-frequency distributions cannot be used to predict population growth. Predicting population growth requires traditional demographic methods (e.g. mapping individuals through time).
\end{abstract}

KEY WORDS: Age-frequency distributions · Annual leaf production - Seagrass demography · Thalassia testudinum

\section{INTRODUCTION}

Large-scale changes in seagrass distribution have direct consequences for the primary and secondary productivity of many coastal systems. In Lower Laguna Madre, Texas, seagrasses cover $70 \%$ of the bottom (Quammen \& Onuf 1993), and in the Thalassia meadow this 1 species accounts for $95 \%$ of the annual gross primary production (Ziegler \& Benner 1998). Seagrass distribution and health have traditionally been assessed by long-term mapping surveys with

\footnotetext{
-Present address: Texas A\&M University, Dept of Oceanography, College Station, Texas 77843-3146, USA.

E-mail:kaldy@nitro.tamu.edu
}

concurrent estimates of biomass and density (Orth \& Moore 1983, Quammen \& Onuf 1993, Onuf 1996a,b, Short \& Burdick 1996, Pulich et al. 1997). Unfortunately, mapping methods require long intervals to detect changes and have limited spatial resolution. With the rapid demise of seagrasses worldwide (Dennison et al. 1993), there is a need for fast, reliable methods and tools to evaluate the expansion or decline of seagrass populations.

Duarte et al. (1994) proposed the use of the 'plastochrone interval' to estimate shoot age and a 'reconstruction method' to predict future population growth or decline. The term 'plastochron' (Schmidt 1924, as cited in Fahn 1990) is defined as the period between successive initiation of 2 leaves or pairs of leaves and is 
identical to the definition of 'plastochrone interval' given explicitly by Jacobs (1979) and indirectly by Patriquin (1973). We have chosen to retain the traditional nomenclature i.e plastochron. Shoot age is estimated from the number of leaf scars along the vertical rhizome and annual leaf production rates (Patriquin 1973, Duarte et al. 1994). Annual leaf production is calculated from the average elapsed time between formation of successive leaves, i.e. the plastochron. The plastochron method was originally developed to standardize plant material for developmental studies (Erickson \& Michelini 1957, Lamoreaux et al. 1978, Ford 1982). The assumption that successive plastochrons were of equal duration has been validated in experimental studies with terrestrial plants (Erickson \& Michelini 1957, Lamoreaux et al. 1978, Vendeland et al. 1982, Birch \& Hutchings 1992). Although seagrass biologists have applied the plastochron concept extensively to estimate shoot age (Patriquin 1973, Brouns 1985a, Gallegos et al. 1992, 1993, 1994, Durako 1994, van Tussenbroek 1994, 1995, Duarte et al. 1994, 1997), the assumption of equal intervals has not been directly assessed for marine angiosperms.

Seagrass shoot age is calculated by dividing the number of leaf scars produced during the life-time of the shoot by the average number of leaves produced during a year. Shoot age calculated in this manner assumes that annual leaf production is equivalent between years; however, this assumption has not been tested using leaf marking. Annual leaf formation can be measured directly using leaf marking (Patriquin 1973, Zieman 1974) or it can be estimated based on cycles detected as variations in internode length along vertical rhizome (Duarte et al, 1994). The assumption that internode length patterns are annual has not been directly confirmed by long-term marking and observation. Estimates of annual leaf formation are often expressed on a per day basis (annual average divided by $365 \mathrm{~d}$ ), which implies that leaf formation occurs at a constant rate throughout the year. It is well known that seagrass leaf production exhibits seasonal patterns, even in tropical regions (Brouns 1985b, van Tussenbroek 1994, 1995). Most studies utilize an 'average annual leaf formation' rate, but only Patriquin (1973) and Durako (1994) provided estimates of variability.

Many of the estimates of annual leaf formation rates that appear in the literature may be inappropriate and should be used with caution. Patriquin (1973) probably overestimated annual leaf production because he extrapolated leaf formation measured during optimal growth conditions (i.e. summer) to represent annual leaf formation rates. Average annual leaf formation has also been calculated from literature surveys (Duarte 1991) and from unpublished sources (Gallegos et al. 1992, 1993; later published in Marbà et al. 1994). We hypothesize that leaf formation (hence plastochron) is site-specific and exhibits interannual variability. Further, we suggest that the application of inappropriate leaf formation rates can seriously misrepresent population age-structure.

The objectives of this study were to critically evaluate the assumption that successive plastochrons are of equal duration and to assess the impact of variability in leaf production on shoot age estimates. Age-frequency distributions for Thalassia testudinum short shoots from a shallow and deep population in a sub-tropical lagoon were developed using site-specific measurements of annual leaf production. Long-term (monthly for $2 \mathrm{yr}$ ) leaf marking measurements were used to assess site-specific, seasonal and interannual variation in leaf formation rates and to estimate confidence limits. The $95 \%$ confidence limits of annual leaf production were used in a basic sensitivity analysis to illustrate the potential impact on age estimates

\section{MATERIALS AND METHODS}

Site description. Two Thalassia testudinum beds within the Lower Laguna Madre (LLM) near Port Isabel, Texas, were monitored from January 1995 to January 1997 (Fig. 1). The shallow site was located in a large seagrass meadow on the eastern side of the Gulf Intracoastal Waterway (GIWW) at a depth of about $1.3 \mathrm{~m}$. The deep site was located on the western side of the GIWW at a depth of about $1.7 \mathrm{~m}$. T. testudinum was dominant at both sites, and Syringodium filiforme and Halodule wrightii grew in scattered patches. Temperature and salinity characteristics were similar at these sites (Kaldy \& Dunton unpubl.). Annual underwater photon flux at the deep site was about $10 \%$ lower than at the shallow site, although at both sites underwater irradiance was above the minimum light requirements for $T$ testudinum (Kaldy 1997).

Plant collection. All core samples were collected haphazardly from within the study sites during the summers of 1995 and 1996. Each site consisted of about $100 \mathrm{~m}^{2}$ of seagrass bed (Fig. 1). These areas were also the focus of concurrent, long-term biomass and density studies (Kaldy \& Dunton unpubl.). Samples were obtained using a $15 \mathrm{~cm}$ diameter core driven $20 \mathrm{~cm}$ into the sediment. Core samples were placed in sealed plastic bags and returned intact to the lab for processing. All sediments were gently washed from the root/rhizome complex to maintain short shoot/rhizome integrity. Only live short shoots (determined by presence of green leaves) that were still attached to the horizontal rhizome were used for age determinations. Overall, we examined 977 shoots from 61 core samples (Table 1). Relative shoot age was based on the number 
of leaf scars + existing leaves. Leaf scars were counted under $25 \times$ magnification using a binocular dissecting scope. All shoots examined were dried and archived. No attempt was made to determine shoot sex.

Determination of leaf formation. Leaf production measurements were made monthly from January 1995 to December 1996 using a modification of Zieman's (1974) leaf marking technique. Briefly, an 18 gauge hypodermic needle was inserted through the leaves within the bundle sheath (above the meristem), causing permanent scarring of the tissues. After an elapsed time of several ( 4 to 6 ) weeks the marked plants were harvested and the number of newly formed leaves (without scar tissue) counted. Of the 30 to 50 shoots that were marked in the field at each site and sampling date, approximately 10 to 15 shoots were retrieved and measured in the lab. Monthly leaf formation was summed over the year to estimate annual rates. The $95 \%$ confidence limits on annual production were calculated as follows: For each month, we calculated the probability that a shoot would produce a given number of leaves ( 0 to 3 leaves). For all the months (8 to 12) the products of the monthly probabilities for all possible sequences (permutations) of numbers of leaves produced were calculated. Then probabilities of each permutation yielding the same total number of leaves per shoot were summed, yielding the overall

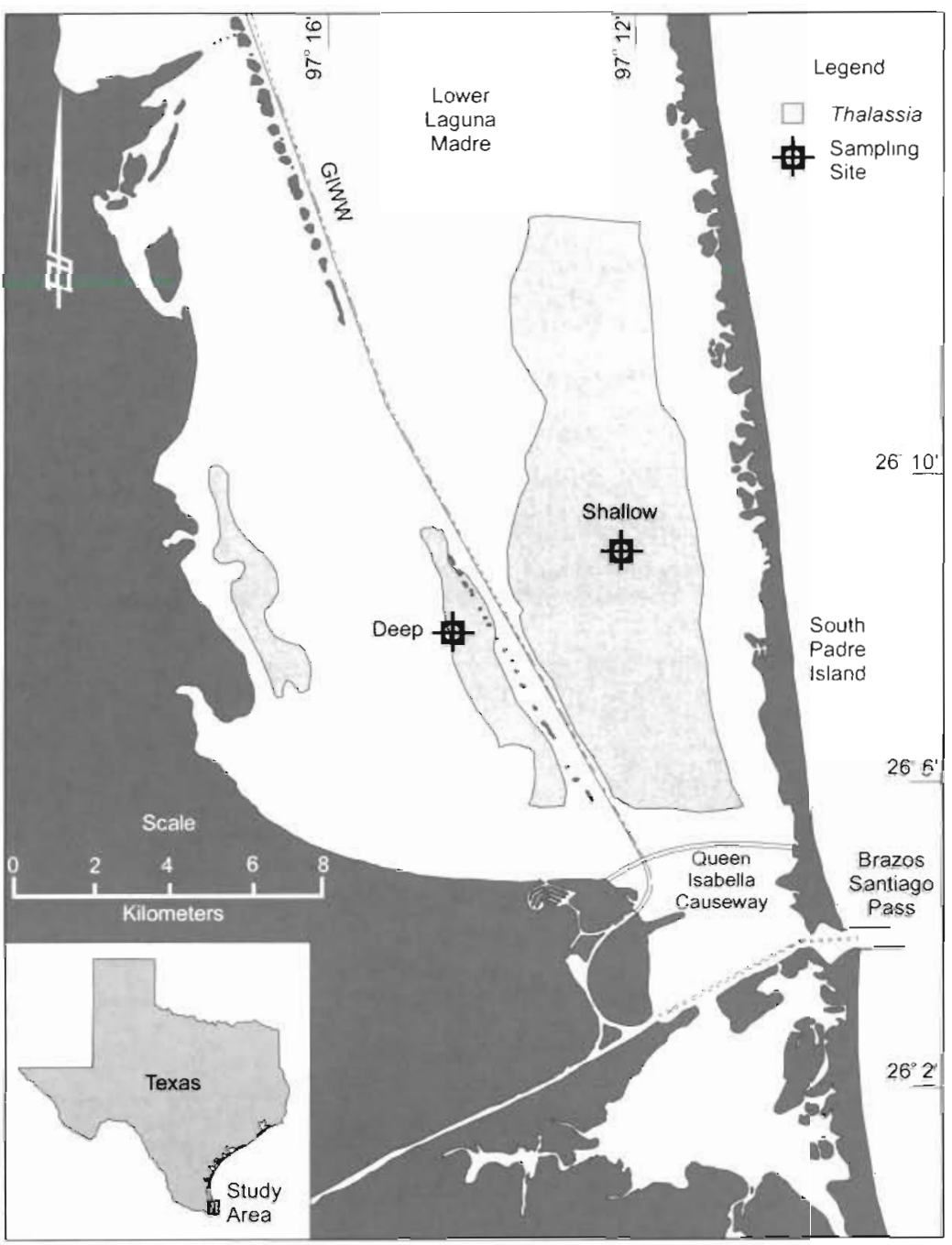

Fig. 1. Thalassia testudinum. Location of the shallow and deep study sites. The shaded portion represents the approximate delineation of $T$ testudinum in Lower Laguna Madre (adapted from Brown \& Kraus 1997). GIWW: Gulf Intracoastal Waterway
Table 1. Thalassia testudinum. Sampling statistics from the shallow and deep sites in Lower Laguna Madre during summer 1995 and 1996. Only live shoots were used in the analysis of age-distributions. Values in parentheses represent the percentage of the total shoots collected that were dead or had at least 1 flowering scar

\begin{tabular}{|ccrrrr|}
\hline $\begin{array}{c}\text { Site } \\
\text { Year }\end{array}$ & Month & $\begin{array}{c}\text { No. of } \\
\text { cores }\end{array}$ & $\begin{array}{c}\text { No. of } \\
\text { shoots }\end{array}$ & $\begin{array}{c}\text { No. } \\
\text { dead }(\%)\end{array}$ & $\begin{array}{c}\text { No. with } \\
\text { flower }(\%)\end{array}$ \\
\hline $\begin{array}{c}\text { Shallow } \\
1995\end{array}$ & Sep & 9 & 220 & $18(8)$ & $62(28)$ \\
1996 & Aug & 17 & 254 & $20(8)$ & $92(36)$ \\
Deep & & & & & \\
1995 & Oct & 16 & 219 & $0(0)$ & $84(38)$ \\
1996 & Aug & 19 & 284 & $11(4)$ & $109(38)$ \\
\hline
\end{tabular}

probability of that combination (e.g. all permutations yielding 10 leaves per shoot during the year). This was done for each combination (i.e. 0 leaves $\mathrm{yr}^{-1}, 1$ leaf $\mathrm{yr}^{-1}$, .36 leaves $\mathrm{yr}^{-1}$ ). The $95 \%$ confidence limits were determined directly from this distribution ( $n=140$ and 144 for the shallow site in 1995 and 1996 respectively, $\mathrm{n}=95$ shoots for the deep site in 1996).

Age-frequency distributions. Short shoot age (yr) was calculated by dividing the total number of leaf scars by the number of leaves produced in a year. Very young shoots have leaf initiation rates that are faster than those of adult shoots (Patriquin 1973). As a result, young shoots have more leaf scars than they should, based on their true chronological age, and are therefore misclassified in the age distributions. Leaf formation and clonal growth rates are minimal during winter 
(Kaldy \& Dunton unpubl.); therefore, the age-frequency distributions were adjusted to represent the age structure during January. Age distributions were adjusted by going back to the raw leaf scar data and subtracting from all shoots the calculated number of leaves produced between January and the sampling date. Monthly leaf production was calculated from leaf marking (see above). In cases where calculated leaf production was greater than the counted number of leaf scars, individuals were removed from further analysis. Subsequently, the age-frequency distribution was re-calculated. As a result, most of the very young shoots formed during spring and summer were removed from the analysis. Differences in the adjusted age-frequency distributions between years (1995 vs 1996) and between sites (shallow vs deep) were assessed using the 2-sample Kolmogorov-Smirnov test. The null hypothesis was identical distributions, i.e. location and dispersion, of the 2 samples (Sokal \& Rohlf 1981)

The 95\% confidence intervals for annual leaf production were used to illustrate how variations in leaf production estimates influence age-frequency distributions. Estimates of the annual leaf formation rates calculated from the upper and lower confidence limits of leaf production were used with the adjusted leaf scar data from the shallow site during 1996. Age-frequency distributions were determined as previously described. Differences in age-frequency distributions based on estimated upper and lower limits of annual leaf formation were tested using the 2-sample KolmogorovSmirnov test (Sokal \& Rohlf 1981).

\section{RESULTS}

\section{Leaf formation}

On an annual basis, monthly leaf formation rates at the shallow and deep site exhibited a bimodal pattern, peak leaf formation rates occurred during spring and fall (Fig. 2). In both 1995 and 1996, leaf formation rates

Table 2. Thalassia testudinum. Mean annual leaf production and $95 \%$ confidence limits based on leaf marking during 1995 and 1996 at the shallow and deep sites in Lower Laguna Madre. No data were collected from the deep site during 1995

\begin{tabular}{|c|c|c|c|c|}
\hline Site & $\begin{array}{l}\text { No. of } \\
\text { months }\end{array}$ & $\begin{array}{c}\text { Lower } \\
\text { limit } \\
\text { (leaves } \mathrm{yr}^{-1} \text { ) }\end{array}$ & $\begin{array}{l}\text { Average } \\
\text { (leaves } \mathrm{yr}^{-1} \text { ) }\end{array}$ & $\begin{array}{c}\text { Upper } \\
\text { limit } \\
\text { (leaves } \mathrm{yr}^{-1} \text { ) }\end{array}$ \\
\hline Shallow 1995 & 9 & 8.1 & 10.5 & 14 \\
\hline Shallow 1996 & 12 & 10.5 & 12.5 & 16 \\
\hline Deep 1996 & 8 & 7.6 & 9.7 & 12.8 \\
\hline
\end{tabular}

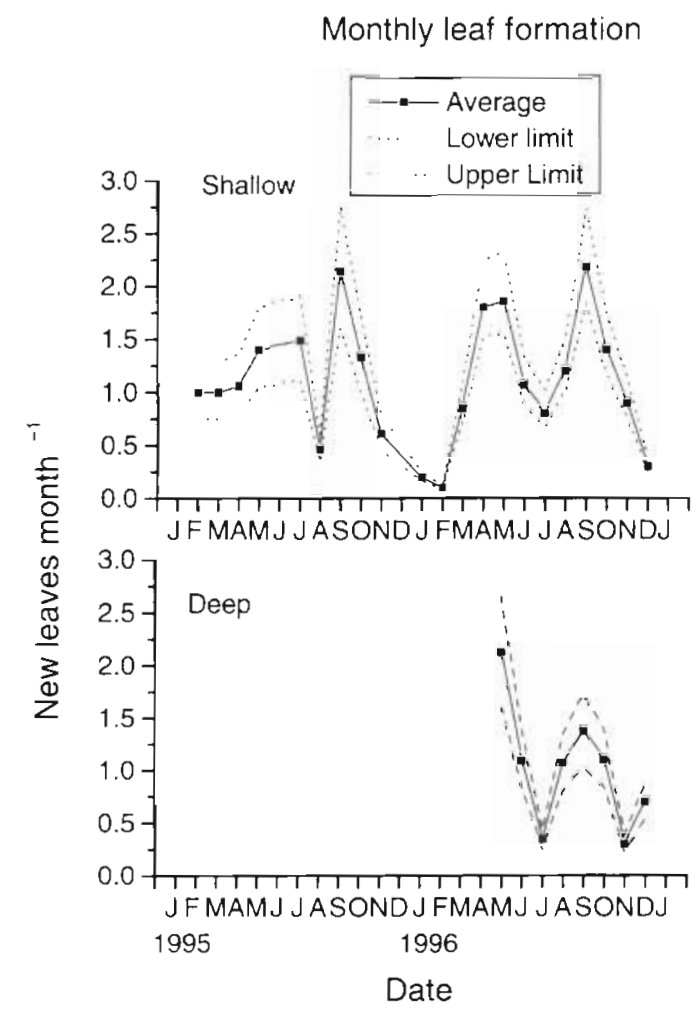

Fig. 2. Thalassia testudinum. Monthly leaf formation rates (means $\pm 95 \%$ confidence limits) for plants at the shallow (February 1995 to December 1996) and deep (May 1996 to December 1996) sites in Lower Laguna Madre

during July and August were 60 to $80 \%$ lower than during September (Fig. 2). The 95\% confidence limits were 20 to $25 \%$ higher and lower than the annual means (Table 2). Leaf formation rates at the shallow site varied between years: 1995 estimates were about $20 \%$ lower than the 1996 estimates (Table 2). Although the differences between sites were not statistically significant, comparison of the limited data set from the deep site suggests that annual leaf formation rates can be site-specific (Fig. 2, Table 2).

\section{Age-frequency data}

The shape of the age-frequency distributions generated for both deep and shallow sites during 1995 and 1996 were anomalous, with fewer shoots in the youngest (i.e. $<1$ yr) age class than in the 1 yr age class (Fig. 3). The oldest shoot was estimated to be about 12 yr old. After adjustment, as previously described, the age-frequency distributions from the shallow site had more individuals in the $<1$ age class than in any other age class in both years. Plants from the deep site in 1996 still had a large group in the 1 yr age class, with fewer shoots in the $<1$ yr age class (Fig. 4). The 
Table 3. Thalassia testudinum. Summary of Kolmogorov-Smirnov comparisons for adjusted age-distributions from 1995 and 1996 at the shallow and deep sites in Lower Laguna Madre. Comparisons were made between sites and between years

\begin{tabular}{|lcccc|}
\hline \multirow{2}{*}{ Distribution } & Comparison & $D_{\text {calc }}$ & $D_{003}$ & $p<0.05$ \\
\hline Age & Deep 95 vs Deep 96 & 0.170 & 0.127 & Yes \\
& Shallow 95 vs Shallow 96 & 0.078 & 0.140 & No \\
Deep 95 vs Shallow 95 & 0.106 & 0.142 & No \\
& Deep 96 vs Shallow 96 & 0.135 & 0.123 & Yes \\
\hline
\end{tabular}

adjusted age-distribution from the deep site in 1996 was significantly different from the deep site 1995 distribution and from the shallow site 1996 distribution (p $<0.05$, Table 3).

\section{Sensitivity analysis}

Annual leaf production calculated using either the upper or the lower confidence limits gave substantially different age estimates than calculations using mean leaf formation rates did, especially for shoots with $>40$ leaf scars (Fig. 5). Adjusted age-frequency distributions calculated using estimated upper and lower limits of annual leaf production (Fig. 6) were significantly different from each other $\left(D_{\text {calc }}=0.197, D_{0.05}=0.124\right.$, $\mathrm{p}<0.05$ ). The upper limit (16 leaves $\mathrm{yr}^{-1}$ ) placed more

\section{Unadjusted Age Distribution}

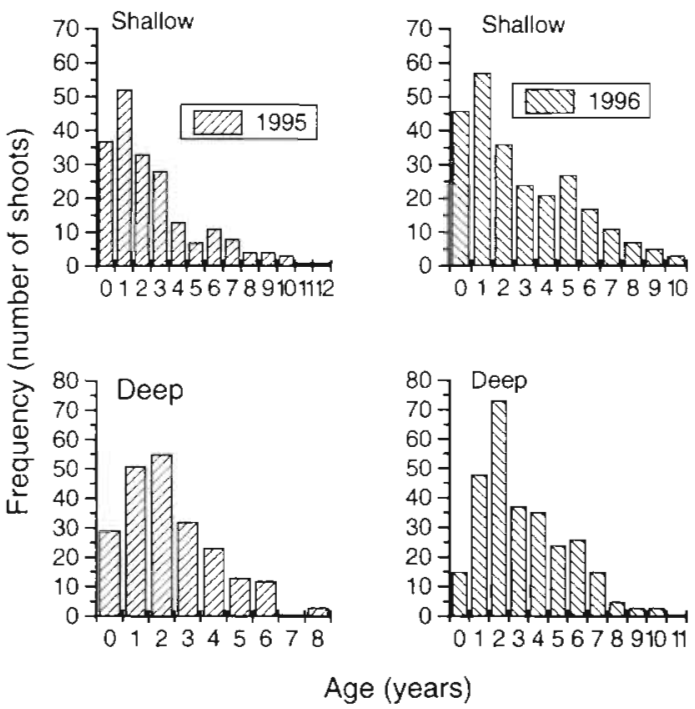

Fig. 3. Thalassia testudinum. Unadjusted age-frequency distributions from the shallow and deep sites during 1995 and 1996 derived from the number of leaf scars on the vertical rhizome and mean annual leaf production estimated at each site

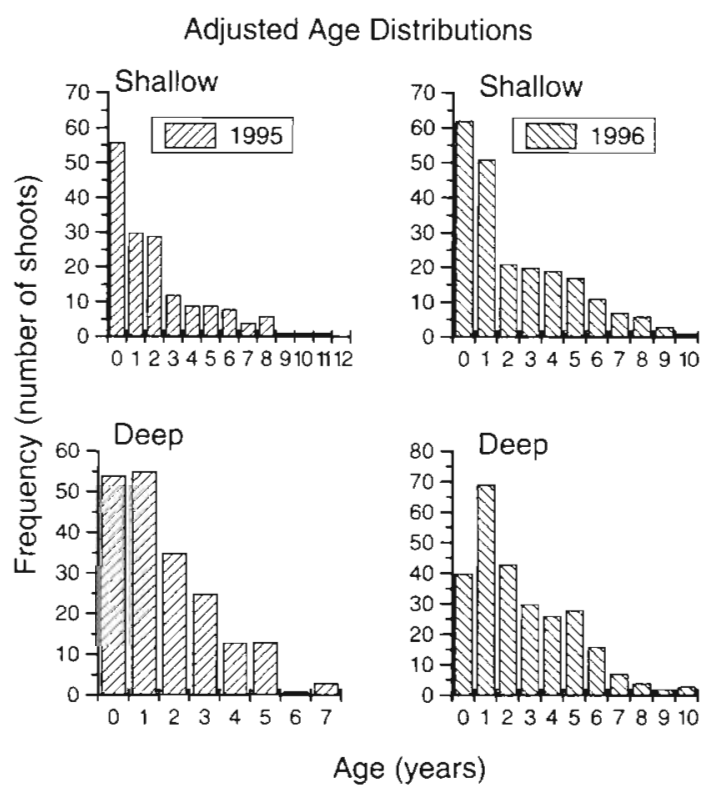

Fig. 4. Thalassia testudinum. Age-frequency distributions from the shallow and deep study site adjusted to represent shoot age during January 1995 and 1996

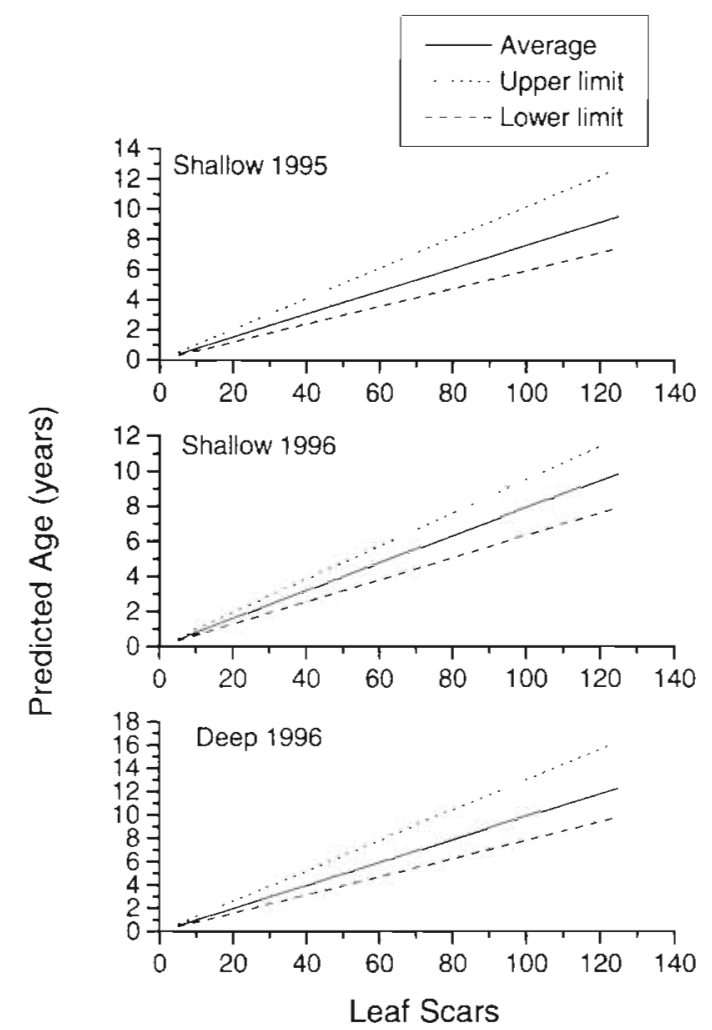

Fig. 5. Thalassia testudinum. Predicted shoot age based on representative values of leaf scars along vertical rhizome and mean annual leaf formation with estimated $95 \%$ confidence limits. No data were collected for the deep site during 1995 


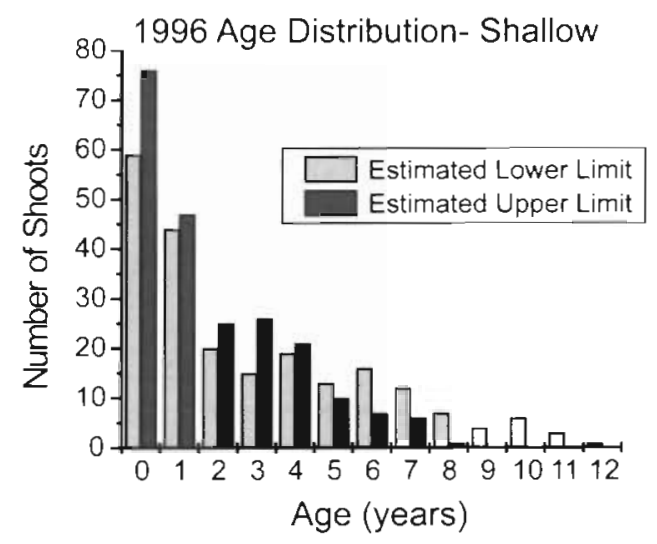

Fig. 6. Thalassia testudinum. Adjusted age-frequency distributions from 1996, calculated using the $95 \%$ confidence limits to illustrate the sensitivity of the age distributions to variability in annual leaf production. Estimated lower limit $=10.5$ leaves $\mathrm{yr}^{-1}$ and estimated upper limit $=16$ leaves $\mathrm{yr}^{-1}$

shoots in the youngest age class, while the lower limit (10.5 leaves $\mathrm{yr}^{-1}$ ) put shoots in older age classes. Maximum shoot age was calculated as 8 and $12 \mathrm{yr}$ using the upper and lower limits respectively.

\section{DISCUSSION}

\section{Plastochron}

Determination of plant (or animal) age is complex and requires cautious data interpretation and validation of assumptions. For example, bivalve shells are produced as layers of calcium carbonate, but the periodicity of these layers can be variable and must be experimentally confirmed for individual species prior to age-determination (Jones 1981, Ropes \& Jearld 1987 ). Fish otolith microstructure has also been used in aging studies, but only after validation of increment formation rates, because environmental parameters are known to influence the periodicity of otolith deposition (Campana \& Neilson 1985). In plants, age determinations can often be made by interpreting anatomical changes in plant organs (e.g., annual rings in temperate trees). However, inadequate validation of assumptions can lead to serious misinterpretation of plant age and demography (e.g. Schaal \& Levin 1976. Werner 1978).

Thalassia testudinum violates the assumption that successive plastochrons are of equal duration (Erickson \& Michelini 1957, Lamoreaux et al. 1978). Leaf initiation rates exhibit clear seasonal fluctuations and appear to be influenced by changes in resource allocation during reproduction. After seed release in August, leaf initiation rates increased by 60 to $80 \%$ (Fig. 2), and rhizome node production increased by $50 \%$ (Kaldy unpubl. data). Changes in resource allocation patterns during fruit maturation probably resulted in depressed leaf and rhizome initiation rates. Several studies have found reduced clonal growth or differential resource allocation during sexual reproduction (Brock 1983, Willson 1983, Haig \& Westoby 1988, Lee 1988, Saulnier \& Reekie 1995). Thus, the application of the plastochron method may be limited to non-flowering seagrass populations.

Substantial interannual variation (about $15 \%$ between 1995 and 1996) indicates that mean annual leaf production based on 1 yr of leaf marking may be inappropriate. Low annual leaf production during 1995 may have been related to reduced underwater irradiance, which increased by $10 \%$ between 1995 and 1996 (Kaldy \& Dunton unpubl.). Marbà et al. (1994) also found interannual variability in Thalassia testudinum leaf formation rates that were associated with changing environmental conditions. The 21 mo of continuous leaf-marking data represent the longest study of $T$. testudinum leaf production with monthly resolution. Additional long-term, fine-scale studies of leaf dynamics would be necessary to get better estimates of interannual variation and its potential impact on shoot age estimates.

The assumption that internode length patterns imprinted on vertical rhizomes represent annual cycles also must be tested by following individual shoots through time. Patterns of variations in internode length have been assumed to be annual based on indirect observations that found that maximum vertical rhizome elongation occurs in the winter (Marbà et al. 1994, p. 5). In contrast, studies in Texas have found reduced rates of leaf production and initiation at times of lower water temperatures (Lee \& Dunton 1996, Kaldy \& Dunton unpubl.). In South Texas, lower water temperatures are a direct consequence of passing winter fronts (Smith 1977). Long-term environmental monitoring in the Lower Laguna Madre indicates substantial interannual variability in the onset of winter fronts (Brown \& Kraus 1997). Thus, interannual variability in meteorological conditions may influence patterns of internode length. Alternatively, leaf formation may be controlled by endogenous rhythms (Ott 1979).

Estimates of the plastochron and resulting annual leaf formation were site-specific, with lower annual leaf formation rates at the deep site. Work at a similar latitude in South Florida also found that annual leaf formation rates were site-specific (Durako 1994). Marbà et al. (1994) found that annual leaf formation rates varied up to $25 \%$ between sites that differed in depth and degree of wave exposure. In contrast, van Tussenbroek (1995) found no differences in annual leaf formation rates among 3 sites in Puerto Morelos, Mexico. Literature values of annual leaf production in Tha- 
lassia testudinum fall between 12 and 31 leaves $\mathrm{yr}^{-1}$ (Patriquin 1973, Duarte 1991, Tomasko \& Lapointe 1991, Gallegos et al.. 1992, 1993, Durako 1994, van Tussenbroek 1995). As a result of this variability, it would be inappropriate to estimate shoot age using leaf formation data from only 1 site or from average literature values. In Lower Laguna Madre, we suspect that the site-specific differences in annual leaf production are related to the lower photon flux at the deep site because all other environmental parameters were virtually identical in the 2 sites (Kaldy \& Dunton unpubl.).

In addition to seasonal and interannual variability in annual leaf production, the large $95 \%$ confidence limits ( \pm 20 to $25 \%$ of the mean values; $n=95$ to 144 ) imply correspondingly large uncertainty in parameters calculated from the plastochron. To illustrate the impact of variable leaf production on age estimates, we used the lower and upper confidence limits of annual leaf production rates to generate different age-frequency distributions and to estimate shoot age (Figs. $5 \& 6$ ). Using leaf production data from the shallow site (Table 2), there is a $95 \%$ probability that a shoot with 50 leaf scars is between 3.5 and 6 yr old using 1995 data and between 3 and 5 yr old using 1996 data. Furthermore, variation in leaf production has a disproportionate effect on the age estimate of shoots with more leaf scars (Fig. 5). Confidence limits for annual leaf production calculated from Durako (1994) are similar in magnitude ( $25 \%$ of the mean) to values recorded in this study. Patriquin (1973) reported $95 \%$ confidence limits on annual leaf production measurements that were several times larger than this study. Duarte et al. (1994) indicate that a large sample size ( $\mathrm{n}>100$ ) is required to report $95 \%$ confidence limits within $10 \%$ of the observed values. The relatively small sample size used in this study ( $\mathrm{n}=10$ to 15 shoots at each sample date) likely accounts for the large confidence limits. In herbaceous perennials, method inaccuracies preclude the precise determination of age (Harper \& White 1974). Estimates of variability in estimated mean plastochron and in estimated mean annual rate of leaf formation are necessary for sensitivity analysis and provide a quantitative evaluation of the age-determinations. The accuracy of annual leaf production for determining shoot age is limited and great caution should be used when interpreting age structures determined with these methods.

\section{Age-frequency distributions}

In most demographic studies of plants and animals, the youngest age classes make up the majority of observations. Seagrass unadjusted age-frequency dis- tributions often have too few young shoots to account for the older shoots in the population. These humpshaped age-frequency distributions have been reported for many seagrass species (Gallegos et al. 1992, 1993, 1994, Durako 1994, Vermaat et al. 1995, Jensen et al. 1996, Marbà et al. 1996, Duarte et al. 1997). There are 3 possible explanations for such age-structures. First, these could be true age-structures, which would imply that the populations are in rapid decline. Using reconstruction methods, both Durako (1994) and Jensen et al. (1996) predicted serious Thalassia testudinum population declines in the same region of Florida Bay. In direct contradiction of these predictions, Jensen et al. (1996) found that $T$. testudinum shoot density had actually increased by $51 \%$ after Durako's (1994) study. Jensen et al. (1996) suggested that the equations of the reconstruction method were flawed and recommended the use of more traditional demographic methods. Preliminary use of the reconstruction method on the unadjusted age-structure data collected in Texas predicted severe seagrass decline, which was directly contradicted by the results of recent mapping efforts documenting the rapid expansion of T. testudinum meadows in the Lower Laguna Madre (Quammen \& Onuf 1993). Furthermore, concurrent long-term biomass and density sampling at the same sites in Lower Laguna Madre did not substantiate the predicted decline (Kaldy \& Dunton unpubl.). Application of the reconstruction method to seagrass populations along the mid-Texas coast (Corpus Christi Bay) also predicted severe decline, yet healthy seagrass stands persist (Chiscano et al. 1995, Dunton \& Major, unpubl. data). A brief survey of the literature indicates that the reconstruction method predicted population decline at $70 \%$ of the sites examined (Gallegos et al. 1993, 1994, Durako 1994, Vermaat et al. 1995, Marbà et al. 1996); however, only 1 study has tested the predictions (Jensen et al. 1996). In general, the reconstruction method appears consistently and incorrectly to predict population decline.

Second, sampling bias could lead to an under-representation of young shoots. This is unlikely because of the large number of cores and shoots (usually $>200$ shoots) sampled in most studies (Gallegos et al. 1992, 1993, 1994, Duarte et al. 1994, Durako 1994, Jensen et al. 1996). Third, bias in the leaf formation measurements may lead to the misclassification of young shoots. Patriquin (1973), documenting age-specific leaf production, found that the first 6 to 7 leaves on a short shoot are produced much faster than subsequent leaves. The tropical palm tree Astrocaryum mexicanum also exhibits age- and size-specific leaf initiation rates (Sarukhán 1978). When unaccounted for, age-specific leaf initiation rates cause shoot age to be overestimated, resulting in misclassification. Misclassi- 
fication of young shoots appears to be common in the seagrass literature and in some cases may be corrected.

The impact of misclassification on age-frequency distributions appears to be site-specific. Adjusted age distributions from the shallow site were closer to expected age structures (Silvertown 1987). Unfortunately, adjusted age structure at the deep site during 1996 continued to exhibit evidence of misclassification. The insufficiency of the correction of the misclassification may be related to site-specific differences in agespecific leaf initiation rates.

\section{Implications for seagrass demography}

Dynamic life-table data are obtained by following a distinct cohort of individuals through time. Usually, individual plants in permanent quadrats are mapped at frequent intervals (Harper 1977). As a result, dynamic life-tables represent the chronological history of a specific cohort of individuals. Population projection matrices, also called matrix population models, are another method of expressing dynamic life-table data (Silvertown 1987, Caswell 1989). Matrix models have been successfully used to examine population parameters of Zostera marina beds in California (Ewanchuk 1995). In contrast, static life-tables are calculated from age-structure data and although they can provide estimates of age-specific survival, mortality and lifeexpectancy, they cannot be used to estimate population growth rates since their construction explicitly assumes a stable population structure with zero growth, i.e. $\lambda=1$ (Krebs 1972, Emmel 1976). Caughley $\&$ Birch (1971) clearly demonstrate that age-frequency data alone cannot be used to predict population growth. In some cases population growth can be predicted using age distribution information together with age-specific fecundities (Michod \& Anderson 1980). However, to date, age-specific fecundity data is not available for Thalassia testudinum.

In pioneering seagrass demography studies, Duarte et al. (1994) and Durako (1994) mistakenly claim to predict population growth, i.e. $\lambda$ ( $M$ in their notation), from age-frequency distributions. Age-frequency data collected with the reconstruction method can be analyzed using static life-tables to provide age-specific mortality and survival estimates. This approach has been used extensively with plants, including aquatic herbs (Harper 1977, Dolan \& Sharitz 1984, Waite 1984, Silvertown 1985). However, Begon et al. (1990, p. 145) emphatically state that the belief that age-structures offer an easy short cut to understanding population dynamics is a snare and a delusion'. Furthermore, all estimates of population age-structure and derived demographic information in seagrasses (including static life-table analysis) are dependent on the estimates of annual leaf formation rates.

The plastochron is an excellent method for standardizing plants to a uniform physiological age and may be useful for determining plant age, provided successive internodes represent equal elapsed time (Lamoreaux et al. 1978, Ford 1982, Birch \& Hutchings 1992). Data collected during this study indicate that Thalassia testudinum violates the assumption of equal elapsed time between successive internodes. As a result, the adequacy of the plastochron method to determine shoot age is limited. Variability between sites, between years, between seasons and within a sample indicates that, at best, annual leaf formation (calculated from plastochrons or measured directly) can only give preliminary estimates of seagrass shoot age.

Age determination is complex as a result of variability between individuals and a stochastic environment. Seagrass biologists have focused exclusively on the demography and age-structure of seagrass ramets, but genet population dynamics are also important to community stability and, thus, warrant attention. Rigorous examination of genet demography will require longterm studies which follow the fate of individual genets through time.

Acknowledgements. This work was completed in partial fulfillment of the PhD requirements from the University of Texas at Austin, Marine Science Department, by J.E.K. S. Herzka, J. Kowalski, and K. S. Lee assisted in the field during various sampling trips. Special thanks to C. Chiscano for help in field sampling, providing insight and helping work out the methods. Dr K. Major, C. Weilhoeffer and H. Miller made helpful suggestions on earlier versions of the manuscript. C. Brown was instrumental in the determination of confidence limits. D. Hockaday at the UT-Pan American Coastal Studies Lab provided logistical support. Drs E. Ingall, P. A. Montagna and C. $P$. Onuf provided comments which improved the manuscript. Correspondence with Drs C. M. Duarte, M. J. Durako, S. Williams, S. Jensen and P. Ewanchuk provided valuable insight on seagrass demographic analysis. We thank 4 anonymous reviewers for their constructive and detailed comments that helped us to further improve the manuscript. This work was supported by grants to $K$. Dunton from the Texas Higher Education Coordinating Board Advanced Research Program (Grant no. 003658-419) and the EPA Gulf of Mexico Program (Grant no. MX994713-95-2). Salary support was provided in part by the E.J. Lund Fellowship to J.E.K. This is UTMSI contribution no. 1081

\section{LITERATURE CITED}

Begon M, Harper JL, Townsend CR (1990) Ecology. Blackwell Scientific Publications, Cambridge, MA

Birch CPD, Hutchings MJ (1992) Analysis of ramet development in the stoloniferous herb Glechoma hederaceae using a plastochron index. Oikos 63:387-394

Brock MA (1983) Reproductive allocation in annual and perennial species of the submerged aquatic halophyte Ruppia. J Ecol 71:811-818 
Brouns JJWM (1985a) The plastochron interval method for the study of the productivity of seagrasses; possibilities and limitations. Aquat Bot 21:71-88

Brouns JJWM (1985b) A comparison of the annual production and biomass in three monospecific stands of the seagrass (Ehrenb.) Aschers. Aquat Bot 23:149-175

Brown CA, Kraus NC (1997) Environmental monitoring of dredging and processes in Lower Laguna Madre, Texas. Final Report to US Army Corps of Engineers. Conrad Blucher Institute, Texas A \& M University-Corpus Christi, Corpus Christi, TX. CTAMU-CC-CBI-96-01

Campana SE, Neilson JD (1985) Microstructure in fish otoliths. Can J Fish Aquat Sci 42:1014-1032

Caswell H (1989) Matrix population models. Sinauer Associates Inc, Sunderland, MA.

Caughley G, Birch LC (1971) Rate of increase. J Wildl Manage 35:658-663

Chiscano C, Kaldy JE, Dunton KH (1995) Age structure and demography of shallow and deep Thalassia testudinum populations in Corpus Christi Bay, Texas. Abstract 13th Estuarine Research Federation Biennial Conference. Estuarine Research Federation, Port Republic, MD

Dennison WC, Orth RJ, Moore KA, Stevenson JC, Carter V, Kollar S, Bergstrom PW, Batuik RA (1993) Assessing water quality with submersed aquatic vegetation: habitat requirements as barometers of Chesapeake Bay health. BioScience 43:86-94

Dolan RW, Sharitz RR (1984) Population dynamics of Ludwigia leptocarpa (Onagraceae) and some factors affecting size hierarchies in a natural population. $\mathrm{J}$ Ecol 72: $1031-1041$

Duarte CM (1991) Allometric scaling of seagrass form and productivity. Mar Ecol Prog Ser 77:289-300

Duarte CM, Marbá N, Agawin $N$, Cebrián J, Enriquez $\mathrm{S}$, Fortes MD, Gallegos ME, Merino M, Olesen B, SandJensen K, Uri J, Vermaat J (1994) Reconstruction of seagrass dynamics:age determinations and associated tools for the seagrass ecologist. Mar Ecol Prog Ser 107:195-209

Duarte CM, Terrados J, Agawin NSR, Fortes MD, Bach S, Kenworthy WJ (1997) Response of a mixed Philippine seagrass meadow to experimental burial. Mar Ecol Prog Ser $147: 285-294$

Durako MJ (1994) Seagrass die-off in Florida Bay (USA): changes in shoot demographic characteristics and population dynamics in Thalassia testudinum. Mar Ecol Prog Ser 110:59-66

Emmel TC (1976) Population biology. Harper \& Row Publishers, New York

Erickson RO, Michelini FJ (1957) The plastochron index. Am J Bot 44:297-305

Ewanchuk PJ (1995) The relative importance of sexual versus asexual reproduction in eelgrass (Zostera marina L.) population growth. Masters thesis, San Diego State University, San Diego, CA

Fahn A (1990) Plant anatomy. Pergamon Press, Oxford

Ford $H$ (1982) Leaf demography and the plastochron index. Biol J Linn Soc 17:361-373

Gallegos ME, Merino M, Marba N, Duarte CM (1992) Flowering of Thalassia testudinum Banks ex König in the Mexican Caribbean: age-dependence and interannual variability. Aquat Bot 43:249-255

Gallegos ME, Merino M, Marba N, Duarte CM (1993) Biomass and dynamics of Thalassia testudinum in the Mexican Caribbean: elucidating rhizome growth. Mar Ecol Prog Ser 95:185-192

Gallegos ME, Marino M, Rodriguez A, Marba N, Duarte CM (1994) Growth patterns and demography of pioneer
Caribbean seagrasses Halodule wrightii and Syringodium filiforme. Mar Ecol Prog Ser 109:99-104

Haig D, Westoby $M$ (1988) Inclusive fitness, seed resources and maternal care. In: Lovett-Doust J, Lovett-Doust L (eds) Plant reproductive ecology. Oxford University Press, Oxford, p 60-79

Harper JL (1977) Population biology of plants. Academic Press, London

Harper JL, White J (1974) The demography of plants. Annu Rev Ecol Syst 5:419-463

Jacobs RPWM (1979) Distribution and aspects of the production and biomass of eelgrass, Zostera marina L., at Roscoff, France. Aquat Bot 7:151-172

Jensen SL, Robbins BD, Bell SS (1996) Predicting population decline: seagrass demographics and the reconstructive technique. Mar Ecol Prog Ser 136:267-276

Jones DS (1981) Repeating layers in the molluscan shell are not always periodic. J Paleontol 55:1076-1082

Kaldy JE (1997) Production dynamics, reproductive ecology and demography of Thalassia testudinum (turtle grass) from the Lower Laguna Madre, Texas. PhD dissertation, University of Texas at Austin, Austin, TX

Krebs CJ (1972) Ecology: the experimental analysis of distribution and abundance. Harper \& Row Publ, New York

Lamoreaux RJ, Chaney WR, Brown KM (1978) The plastochron index: a review after two decades of use. Am J Bot 65:586-593

Lee TD (1988) Patterns of fruit and seed production. In: Lovett-Doust J, Lovett-Doust L (eds) Plant reproductive ecology. Oxford University Press, Oxford, p 179-202

Lee KS, Dunton KH (1996) Production and carbon reserve dynamics of the seagrass Thalassia testudinum in Corpus Christi Bay, Texas. Mar Ecol Prog Ser 143:201-210

Marbà N, Gallegos ME, Merino M, Duarte CM (1994) Vertical growth of Thalassia testudinum: seasonal and interannual variability. Aquat Bot 47:1-11

Marbà N, Duarte CM, Cebrián J, Gallegos ME, Olesen B, Sand-Jensen K (1996) Growth and population dynamics of Posidonia oceanica on the Spanish Mediterranean coast: elucidating seagrass decline. Mar Ecol Prog Ser 137: 203-213

Michod RE, Anderson WW (1980) On calculating demographic parameters from age frequency data. Ecology 61 : 265-269

Onuf CP (1996a) Biomass patterns in seagrass meadows of the Laguna Madre, Texas. Bull Mar Sci 58:404-420

Onuf CP (1996b) Seagrass responses to long-term light reduction by brown tide in upper Laguna Madre, Texas: distribution and biomass patterns. Mar Ecol Prog Ser 138: $219-231$

Orth RJ, Moore KA (1983) Chesapeake Bay: an unprecedented decline in submerged aquatic vegetation. Science 222:51-53

Ott JA (1979) Persistence of a seasonal growth rhythm in Posidonia oceanica (L.) Delile under constant conditions of temperature and illumination. Mar Biol Lett 1:99-104

Patriquin D (1973) Estimation of growth rate, production and age of the marine angiosperm Thalassia testudinum König. Caribb J Sci 13:111-123

Pulich W, Blair C, White WA (1997) Current status and trends of seagrasses in the northern Corpus Christi Bay national estuary region. Corpus Christi Bay National Estuary Program, Texas Natural Research Conservation Commission, Austin, TX. CCBNEP-20

Quammen ML, Onuf CP (1993) Laguna Madre: seagrass changes continue decades after salinity reduction. Estuaries $16: 302-310$ 
Ropes JW, Jearld A (1987) Age determination of ocean bivalves. In: Sommerfelt RC, Hall GE (eds) Age and growth of fish. Iowa State University Press, Ames, IA, p $517-526$

Sarukhán J (1978) Studies on the demography of tropical trees. In: Tomlinson PB, Zimmerman MiH (eds) Tropical trees as living systems. Cambridge University Press, Cambridge, p 163-184

Saulnier TP, Reekie EG (1995) Effect of reproduction on nitrogen allocation and carbon gain in Oenothera biennis. J Ecol 83:23-29

Schaal BA, Levin. DA (1976) The demographic genetics of Liastris cylindraceae Michx. (compositae). Am Nat 110: 191-206

Schmidt A (1924) Histologische Studien an phanerogamen Vegetationspunkten. Bot Arch 8:345-404

Short FT, Burdick (1996) Quantifying eelgrass habitat loss in relation to housing development and nitrogen loading in Waquoit Bay, Massachusetts. Estuaries 19:730-739

Silvertown JW (1985) Survival, fecundity and growth of wild cucumber, Echinocystis lobata. J Ecol 73:841-849

Silvertown JW (1987) Introduction to plant population ecology. John Wiley \& Sons Inc, New York

Smith NP (1977) A note on winter temperature variation in a shallow seagrass flat. Limnol Oceanogr 22:1079-1082

Sokal RR, Rohlf FJ (1981) Biometry. WH Freeman and Co, New York

Tomasko DA, Lapointe BE (1991) Productivity and biomass of Thalassia testudinum as related to water column nutrient

Editorial responsibility: Otto Kinne (Editor),

Oldendorf/Luhe, Germany availability and epiphyte levels: field observations and experimental studies. Mar Ecol Prog Ser 75:9-17

van Tussenbroek BI (1994) Aspects of the reproductive ecology of Thalassia testudinum in Puerto Morelos Reef Lagoon, Mexico. Bot Mar 37:413-417

van Tussenbroek BI (1995) Thalassia trstudinum leaf dynamics in a Mexican Caribbean coral reef lagoon. Mar Biol $122: 33-40$

Vendeland JS, Sinclair TR, Spaeth SC, Cortes PM (1982) Assumptions of the plastochron index: evaluation with soya bean under field drought conditions. Ann Bot 50: $673-680$

Vermaat J, Agawin NSR, Duarte CM, Fortes MD, Marbà N Uri JS (1995) Meadow maintenance, growth and productivity of a mixed Philippine seagrass bed. Mar Ecol Prog Ser 124:215-225

Waite S (1.984) Changes in the demography of Plantago coronopus at two coastal sites. J Ecol 72:809-826

Werner PA (1978) On the determination of age in Liastris aspera using cross-sections of corms: implications for past demographic studies. Am Nat 112:1113-1120

Willson MF (1983) Plant reproductive ecology. John Wiley \& Sons, New York

Ziegler S, Benner R (1998) Ecosystem metabolism in a subtropical, seagrass-dominated lagoon. Mar Ecol Prog Ser 173:1-12

Zieman JC (1974) Methods for the study of growth and production of turtle grass, Thalassia testudinum König. Aquaculture 4:139-144

Submitted: June 29, 1998; Accepted: January 7, 1999 Proofs received from author(s): April 30, 1999 